\title{
PENDEKATAN OPSI CASH-OR-NOTHING UP AND IN BARRIER UNTUK PENENTUAN NILAI PREMI ASURANSI PERTANIAN*
}

\author{
Yunita Wulan Sari ${ }^{1 \ddagger}$ and Gunardi $^{2}$ \\ 1Department of Mathematics, Universitas Gadjah Mada (UGM), Indonesia, yunita-ws@ugm.ac.id \\ 2Department of Mathematics, Universitas Gadjah Mada (UGM), Indonesia, gunardi@ugm.ac.id \\ Fcorresponding author
}

Indonesian Journal of Statistics and Its Applications (elSSN:2599-0802)

Vol 4 No 3 (2020), 557 - 565

Copyright (C) 2020 Yunita Wulan Sari and Gunardi. This is an open-access article distributed under the Creative Commons Attribution License, which permits unrestricted use, distribution, and reproduction in any medium, provided the original work is properly cited.

\begin{abstract}
Crop insurance is a type of insurance that provides protection to farmers who hold an insurance policy for losses due to crop failure. Extreme weather, especially rainfall, has been the main cause of the crop failure. Therefore, the type of crop insurance based on weather or rainfall must be developed and applied. This paper will discuss the cashor-nothing up and in barrier option approach for determining insurance premiums where the risk of loss in terms of high rainfall, then compare it to the Black-Scholes option approach. In this approach, the claim limit is based on the rainfall index and the value of the barrier is determined according to the size of the extreme rainfall. We use cumulative rainfall data in the first subround in Sleman regency as a case study. The conclusions obtained are barrier value has a negative effect on the value of insurance premiums and claim limit value has a positive effect. Besides the premium value with this barrier option approach is cheaper than the Black-Scholes option approach, this approach method more interesting to apply because of the barrier value addition.
\end{abstract}

Keywords: crop insurance, premium value, up and in barrier option, weather index.

\section{Pendahuluan}

Seiring dengan terjadinya perubahan iklim di beberapa tahun terakhir, kejadian iklim dan cuaca ekstrim telah meningkat secara signifikan, baik dalam frekuensi maupun

\footnotetext{
* Received Jun 2020; Accepted Nov 2020; Published online on Nov 2020
} 
kuantitasnya. Akibatnya, petani harus menghadapi risiko gagal panen yang disebabkan oleh banjir, kekeringan, ataupun serangan hama tanaman pada setiap musim tanam. Upaya untuk menekan risiko tersebut sebenarnya sudah banyak dilakukan oleh petani, tetapi itu semua belum cukup. Mereka masih memerlukan dukungan dan perlindungan formal dari asuransi pertanian yang berbasis iklim/cuaca. Sistem asuransi ini memberikan perlindungan, jaminan, atau ganti rugi kepada petani selaku pemilik polis asuransi ketika kondisi cuaca/iklim yang tidak diharapkan terjadi pada periode pertumbuhan tanaman yang diasuransikan (Okine, 2014). Menurut Estiningtyas (2015), jenis asuransi ini berpeluang untuk dikembangkan dan diaplikasikan di Indonesia.

Pemerintah Republik Indonesia telah membuat program asuransi pertanian dalam rangka menciptakan satu alternatif skema pendanaan dalam pembagian risiko yang mungkin terjadi dalam kegiatan usaha pertanian. Selanjutnya, PT Asuransi Jasa Indonesia (Jasindo) diberikan wewenang untuk mengelola program asuransi tersebut. PT Jasindo telah menetapkan besarnya premi yang ditanggung oleh petani peserta asuransi tersebut adalah Rp. 180.000,-/hektar (ha) untuk setiap musim tanam dengan plafon penjaminan kerugian akibat gagal panen adalah sebesar Rp.6.000.000,/ha/musim tanam. Namun, besaran premi itu tidak ditanggung sepenuhnya oleh petani karena pemerintah memberikan subsidi pembayaran premi sebesar $80 \%$ atau Rp.144.000,-/ha/musim tanam. Selain itu, besarnya premi yang harus dibayarkan dihitung secara proporsional terhadap luas lahan yang diasuransikan. Skema asuransi pertanian di atas merupakan subsidi awal kepada petani untuk meningkatkan persepsi dan motivasi petani mengenai asuransi, mengingat asuransi ini sangat bermanfaat untuk mengurangi risiko kerugian petani saat terjadi gagal panen. Diharapkan beberapa tahun ke depan petani sudah bisa mandiri dan secara perlahan pemerintah akan mengurangi besarnya subsidi tersebut. Sebagai negara agraris, seharusnya asuransi pertanian ini sudah berkembang pesat di Indonesia. Namun, pada kenyataannya sampai saat ini belum perusahaan asuransi lain belum ada yang membuat produk asuransi pertanian ini. Selain itu, tingkat partisipasi petani dinilai juga masih kurang.

Opsi merupakan hak yang diberikan kepada pemegang opsi untuk membeli atau menjual saham pada waktu dan pada harga tertentu. Berbagai model telah dikembangkan untuk menentukan nilai teoritis opsi, salah satunya adalah model Black Scholes yang diperkenalkan oleh Black \& Scholes (1973). Menurut Okine (2014) dan Putri et al. (2017), metode Black-Scholes juga dapat digunakan untuk menentukan atau menghitung premi asuransi ketika hasil produksi mengalami penurunan di bawah standar karena dipengaruhi oleh curah hujan. Opsi barrier adalah suatu kontrak opsi, dimana kontrak tersebut dapat diaktifkan atau dinon-aktifkan jika harga saham di pasar menembus suatu level harga tertentu (barrier) (Higham, 2004; Wilmott, 2001). Pendekatan opsi barrier telah digunakan oleh Hwang \& Shie (2015) untuk menentukan harga premi asuransi deposito. Berdasarkan sifat dan karakteristik opsi barrier, paper ini akan membahas penentuan premi asuransi pertanian dengan pendekatan nilai opsi cash-or-nothing up and in barrier, dimana risiko kerugian dilihat dari faktor curah hujan. Selain itu, metode pendekatan ini akan dibandingkan dengan metode pendekatan opsi Black-Scholes. 


\section{Metodologi}

\subsection{Data}

Data curah hujan kumulatif per subround di Kabupaten Sleman yang diperoleh dari BPS Sleman digunakan sebagai studi kasus pada penelitian ini. Data tersebut dimulai dari tahun 2010 sampai tahun 2019. Data yang digunakan adalah data subround pertama karena pada bulan Januari-April sudah memasuki musim penghujan, sehingga petani mulai menanam padi.

Tabel 1: Data curah hujan pada subround pertama di Kabupaten Sleman.

\begin{tabular}{cc}
\hline Tahun & Curah hujan $(\mathrm{mm})$ \\
\hline 2010 & 1377 \\
2011 & 1667 \\
2012 & 1619 \\
2013 & 1221 \\
2014 & 1170,6 \\
2015 & 1404 \\
2016 & 1614 \\
2017 & 1693 \\
2018 & 1595 \\
2019 & 1767 \\
\hline
\end{tabular}

\subsection{Metode Penelitian}

Pada penelitian ini akan dicari model penentuan premi asuransi dengan pendekatan opsi cash or nothing up and in barrier, kemudian membandingkannya dengan premi asuransi dengan pendekatan opsi Black Scholes. Opsi merupakan hak yang diberikan kepada pemegang opsi untuk membeli atau menjual saham pada waktu dan pada harga tertentu. Model pergerakan harga saham dinyatakan sebagai

$$
d S_{t}=\mu d t+\sigma d W_{t}
$$

dengan $S_{t}$ adalah harga saham pada saat $\mathrm{t}$ dan $W_{t}$ adalah proses Wiener sehingga didapatkan $\ln \left(\frac{S_{t+\Delta t}}{S_{t}}\right) \sim N\left(\mu \Delta t, \sigma^{2} \Delta t\right)$.

Opsi cash or nothing merupakan salah satu jenis opsi yang termasuk dalam binary options, yaitu opsi yang hanya memiliki dua kemungkinan hasil. Pada opsi beli cash or nothing, fungsi keuntungannya (payoff) diberikan sebagai berikut :

$$
C^{\text {cash }}\left(S_{t}, T\right)= \begin{cases}P, & \text { jika } S_{T}>K \\ 0, & \text { jika } S_{T}<K\end{cases}
$$

sedangkan fungsi payoff opsi jual cash or nothing adalah

$$
P^{\text {cash }}\left(S_{t}, T\right)=\left\{\begin{array}{ll}
P, & \text { jika } S_{T}<K \\
0, & \text { jika } S_{T}>K
\end{array} .\right.
$$

Pada asuransi berbasis indeks, $P$ merupakan besarnya tunjangan yang akan diperoleh pemegang polis dan bernilai positif. Sedangkan $S_{T}$ merujuk pada curah hujan 
kumulatif pada periode tertentu. $P$ diberikan perusahaan asuransi kepada pemegang polis jika kumulatif curah hujan kurang dari batas klaim yang telah ditentukan oleh pihak asuransi. Dengan demikian, penentuan premi dengan pendekatan opsi akan merujuk pada opsi jual, yaitu

$$
P^{c a s h}\left(S_{t}, T\right)=e^{-r T} E[\max (P, 0)] .
$$

Dengan demikian, besarnya premi asuransi berbasis indeks curah hujan yang memiliki panjang periode asuransi, $\mathrm{T}$, dan nilai $\mathrm{K}$ yang merujuk pada batas klaim yang pada kasus ini dinotasikan dengan $R_{T}$ dengan pendekatan opsi black scholes dapat dihitung dengan persamaan

$$
\operatorname{Premi}_{B S}=e^{-r T} \int_{-\infty}^{K} P f\left(S_{t}\right) d S_{t}=P e^{-r T} N\left(-d_{2}\right)
$$

dengan $d_{2}=\frac{\ln \left(\frac{R_{0}}{R_{T}}\right)+\left(r-\frac{1}{2} \widehat{\sigma}^{2}\right) T}{\widehat{\sigma} \sqrt{T}}$.

Opsi barrier adalah suatu kontrak opsi, dimana kontrak tersebut dapat diaktifkan atau dinon-aktifkan jika harga saham di pasar menembus suatu level harga tertentu (barrier). Up and in barrier option adalah salah satu jenis opsi barrier yang hanya bisa dilaksanakan ketika harga saham di pasar menyentuh nilai barrier yang nilainya lebih tinggi daripada harga saham di pasar pada saat $\mathrm{t}=0$. Proses pergerakan harga saham pada waktu t dan mencapai nilai barrier (B) merupakan sebuah mixed distribution antara suatu densitas dan probabilitas pergerakan harga saham mencapai $B$ sebelum waktu t. Oleh karena itu, fungsi kepadatan peluang $\ln \left(S_{t}\right)$ menurut Björk (1998) dapat dituliskan sebagai berikut

$$
\begin{aligned}
f\left(\ln \left(S_{t}\right)\right)=\phi & \left(\ln \left(S_{t}\right) ; \mu t+\ln \left(S_{0}\right), \sigma^{2} t\right) \\
& -\exp \left(-\frac{2 \mu\left(\ln \left(S_{0}\right)-\ln (B)\right)}{\sigma^{2}}\right) \phi\left(\ln \left(S_{t}\right) ; \mu t-\ln \left(S_{0}\right)+2 \ln (B), \sigma^{2} t\right)
\end{aligned}
$$

dimana $\phi(x ; \alpha, \beta)$ menyatakan fungsi kepadatan peluang distribusi normal dengan mean $\alpha$ dan variansi $\beta$.

Berdasarkan persamaan (1) dan (2), besarnya premi asuransi dengan pendekatan opsi cash-or-nothing up and in put dapat dihitung dengan persamaan berikut:

$$
\text { Premi }=P e^{-r T}\left(N\left(d_{1}\right)-N\left(d_{2}\right)+\left(\frac{R_{b}}{R_{0}}\right)^{\frac{2 r}{\hat{\sigma}^{2}}-1} N\left(d_{3}\right)\right)
$$

dengan

- $\quad d_{1}=\frac{\ln \left(\frac{R_{0}}{R_{b}}\right)+\left(r-\frac{1}{2} \widehat{\sigma}^{2}\right) T}{\widehat{\sigma} \sqrt{T}}$,

- $d_{2}=\frac{\ln \left(\frac{R_{0}}{R_{T}}\right)+\left(r-\frac{1}{2} \widehat{\sigma}^{2}\right) T}{\widehat{\sigma} \sqrt{T}}$,

- $d_{3}=\frac{\ln \left(\frac{R_{0}}{R_{b}}\right)-\left(r-\frac{1}{2} \widehat{\sigma}^{2}\right) T}{\widehat{\sigma} \sqrt{T}}$,

- $\hat{\sigma}^{2}$ : estimasi variansi Inrasio data historis curah hujan, 
- $T$ : panjang periode asuransi,

- $r$ : tingkat suku bunga bebas risiko,

- $R_{0}$ : banyaknya curah hujan pada saat $\mathrm{t}=0$,

- $R_{b}$ : besarnya barrier,

- $R_{T}$ : batas klaim.

Asumsi yang harus terpenuhi pada penentuan premi asuransi pertanian berbasis besarnya curah hujan dengan pendekatan opsi ini adalah

1. Inrasio data historis curah hujan berdistribusi normal.

$$
\text { lnrasio }=\ln \left(\frac{R_{t+1}}{R_{t}}\right)
$$

dengan $R_{t+1}$ adalah curah hujan kumulatif pada saat $\mathrm{t}+1$ dan $R_{t}$ adalah curah hujan kumulatif pada saat $t$.

2. Nilai batas klaim ditentukan dengan menggunakan indeks curah hujan.

3. Pada pendekatan opsi cash-or-nothing up and in, nilai barrier merupakan curah hujan yang lebih tinggi daripada curah hujan pada saat $t=0$.

\section{Hasil dan Pembahasan}

Pada penelitian ini, tunjangan klaim akan diberikan perusahaan asuransi kepada pemegang polis apabila terjadi gagal panen akibat curah hujan tinggi. Pada Gambar 1, terlihat bahwa terdapat korelasi negatif antara curah hujan dengan produktivitas padi pada subround pertama di Kab. Sleman. Artinya semakin tinggi curah hujan, produktivitas padi akan menurun.

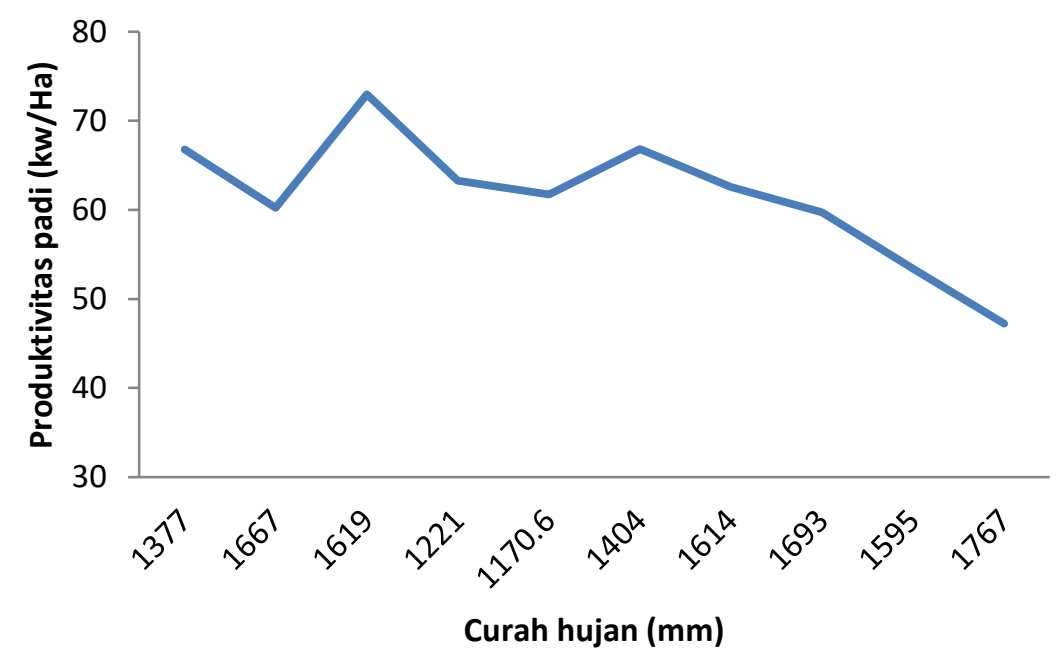

Gambar 1: Produktivitas padi subround pertama di Kab. Sleman tahun 2010-2019.

Pengecekan asumsi normalitas Inrasio data historis curah hujan dilakukan dengan uji Kolmogorov Smirnov dimana $\mathrm{H}_{0}$ menyatakan data mengikuti distribusi normal. Diperoleh nilai $p_{-}$value 0,2 . Hal ini menunjukkan bahwa data tersebut berdistribusi normal pada tingkat signifikansi $5 \%$. 
Penentuan batas klaim dilakukan dengan mencari persentil ke 10, 25, dan 50 dari data curah hujan kumulatif (Tabel 1). Didapatkan nilai persentil ke 10, 25, dan 50 masing-masing adalah 1175,64 mm; $1338 \mathrm{~mm}$; dan 1604,5 mm. Kebutuhan air untuk setiap tanaman berbeda-beda. Kebutuhan air pada tanaman padi berkisar antara 350$700 \mathrm{~mm} / \mathrm{musim}$ tanam (Subagyono et al., 2004). Tanaman padi akan mengalami pembusukan akar jika mendapatkan air berlebihan dari yang dibutuhkan, bahkan akan mengalami kematian apabila penggenangan air terjadi dalam waktu yang lama. Akibatnya petani akan mengalami gagal panen. Oleh karena itu, nilai barrier pada penelitian ini ditentukan sebesar $700 \mathrm{~mm} / \mathrm{musim}$ tanam. Besarnya curah hujan pada subround sebelumnya digunakan sebagai nilai $R_{0}$. Besarnya tunjangan klaim disesuaikan dengan besarnya tunjangan klaim yang diberikan oleh PT. Jasindo, yaitu sebesar Rp. 6.000.000,-/Ha/masa tanam.

Pada metode pendekatan Black Scholes, berapapun besarnya curah hujan sepanjang periode kontrak asuransi, petani pemegang polis akan mendapatkan tunjangan asuransi selama curah hujan pada waktu jatuh tempo kurang dari batas klaim. Namun, pendekatan Up and in barrier option pada penentuan premi asuransi pertanian mengakibatkan petani pemegang polis akan mendapatkan tunjangan asuransi apabila selama periode kontrak, curah hujan pernah mencapai nilai barrier (yang nilainya lebih tinggi daripada curah hujan pada saat kontrak disepakati) dan pada saat jatuh tempo, curah hujan tidak lebih dari nilai batas klaim.

Besarnya premi dengan pendekatan opsi cash-or-nothing up and in barrier dan besarnya premi yang dihitung dengan pendekatan opsi cash-or-nothing black scholes dapat dilihat pada Tabel 2. Dari Tabel 2 tersebut terlihat pula bahwa besarnya premi dengan pendekatan opsi cash-or-nothing up and in barrier lebih rendah. Hal ini dikarenakan adanya penambahan nilai barrier membuat peluang terjadinya klaim lebih kecil sehingga premi yang dibayarkan lebih rendah.

Tabel 2: Nilai Premi.

\begin{tabular}{llll}
\hline & Asuransi 1 & Asuransi 2 & Asuransi 3 \\
\hline Batas Klaim & $1.175,64$ & 1.338 & $1.604,5$ \\
Nilai Barrier & 700 & 700 & 700 \\
Curah hujan pada t=0 & 554 & 554 & 554 \\
Besarnya Klaim & 6.000 .000 & 6.000 .000 & 6.000 .000 \\
Suku Bunga & 0,065 & 0,065 & 0,065 \\
Lama Asuransi & 4 bulan & 4 bulan & 4 bulan \\
\hline Harga Premi (Rp.) & & & $780.440,67$ \\
Up and In Barrier & $780.438,35$ & $780.440,65$ & \\
Black scholes & $5.871 .395,90$ & $5.871 .398,20$ & $5.871 .398,22$ \\
\hline
\end{tabular}

Perbandingan performa pendekatan opsi cash-or-nothing up and in barrier dan pendekatan opsi Black-Scholes dilihat dari nilai barrier, batas klaim, dan $R_{0}$ masingmasing disajikan pada Gambar 2. 


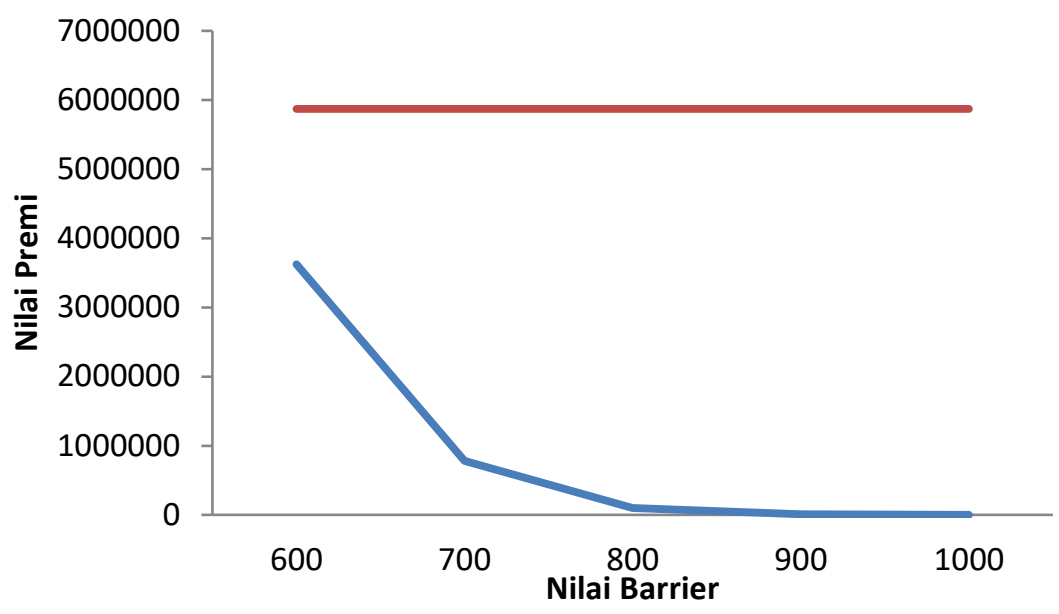

(a)

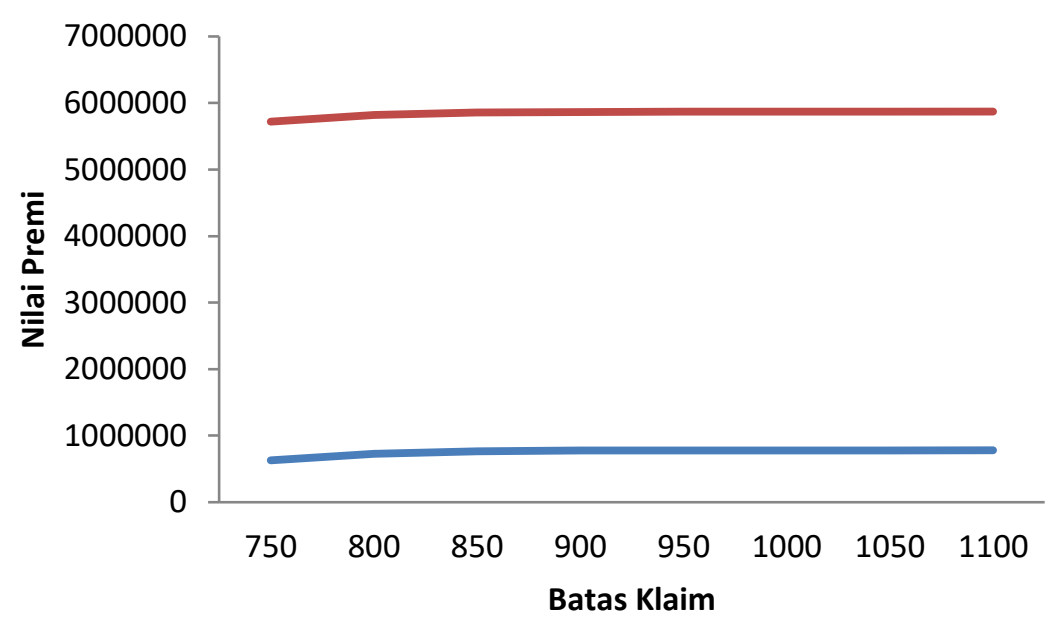

(b)

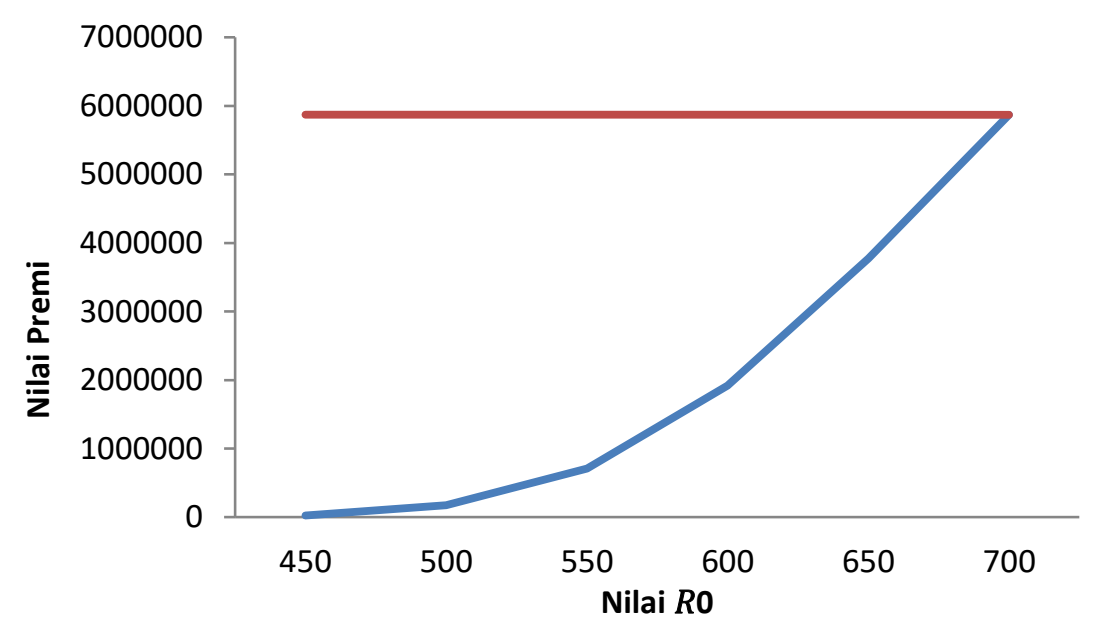

(c)

- pendekatan opsi cash-or-nothing up and in barrier

Pendekatan opsi Black Scholes

Gambar 2: Besarnya Premi untuk beberapa (a) nilai barrier, (b) batas klaim, dan (c) nilai $R_{0}$. 
Berdasar Gambar 2, terlihat bahwa nilai barrier berpengaruh negatif terhadap nilai premi. Artinya, semakin tinggi nilai barrier, maka nilai premi semakin rendah. Hal ini dikarenakan tingginya nilai barrier membuat peluang terjadinya klaim semakin kecil. Namun, tidak berlaku bagi pendekatan opsi Black Scholes karena pendekatan opsi ini tidak dipengaruhi oleh barrier. Sebaliknya, semakin naik nilai batas klaim dan nilai $R_{0}$, nilai premi juga akan semakin naik.

\section{Kesimpulan}

Model pendekatan cash or nothing up and in barrier option bisa menjadi alternatif yang menarik dalam penentuan harga premi asuransi berbasis pada curah hujan, dimana selama ini asuransi pertanian yang dikelola PT. Jasindo berbasis pada besarnya tingkat kerusakan yang menyebabkan gagal panen. Model pendekatan ini lebih masuk akal dan menarik jika dibandingkan dengan model pendekatan opsi Black-Scholes. Penambahan nilai barrier membuat tidak semua polis akan mendapatkan tunjangan klaim di akhir kontrak asuransi. Tunjangan klaim hanya akan diberikan ketika besarnya curah hujan lebih dari ambang batas kebutuhan air yang diperlukan tanaman padi selama musim tanam (barrier) dan kurang dari curah hujan yang menjadi batas klaim yang dtentukan perusahaan asuransi. Adanya batasan ini membuat peluang terjadinya klaim lebih rendah dan harga premi menjadi lebih murah. Besarnya barrier berpengaruh negatif terhadap premi. Namun, besarnya batas klaim dan curah hujan pada saat kontrak asuransi berkorelasi positif dengan harga premi.

\section{Daftar Pustaka}

Björk, T. (1998). Arbitrage Theory in Continous Time. New York (US): Oxford University Press.

Black, F., \& Scholes, M. (1973). The Pricing of Options and Corporate Liabilities. Journal of Economic Theory, 10: 239-257.

Estiningtyas, W. (2015). Asuransi Pertanian Berbasis Indeks Iklim: Opsi Pemberdayaan dan Perlindungan Petani Terhadap Risiko Iklim. Jurnal Sumberdaya Lahan, 9(1): 51-64.

Higham, D. J. (2004). An Introduction to Financial Option Valuation, Mathematics, Stochastics, and Computation. Cambridge: Department of Mathematics University of Strathclyde.

Hwang, D. Y., \& Shie, F. S. (2015). The Barrier Option in Deposit Insurance with Bankruptcy Cost. Research Gate Publication.

Okine, A. N. (2014). Pricing of Index Insurance Using Black-Scholes Framework: A Case Study of Ghana [Thesis]. Illinois (US): Illinois State University.

Putri, I. A. G. K., Dharmawan, K., \& Tastrawati, N. K. T. (2017). Perhitungan Harga Premi Asuransi Pertanian yang Berbasis Indeks Curah Hujan Menggunakan Metode Black Scholes. E-Jurnal Matematika, 6(2): 161-167. 
Subagyono, K., Dariah, A., Surmaini, E., \& Kurnia, U. (2004). Pengelolaan Air pada Tanah Sawah (Tanah Sawah dan Teknologi Pengelolaannya Eds : Agus F). Jakarta (ID): Puslitbang Tanah dan Agroklimat, Puslitbang Pertanian, Departemen Pertanian Indonesia.

Wilmott, P. (2001). Paul Wilmott Introduces Quatitative Finance. Chichester (UK): John Willey and Sons Ltd. 